\title{
nature
}

\section{Short-circuit to be avoided by bioethics committees}

\section{A decision by the French national bioethics committee to recommend a ban on human cloning for reproductive purposes sets a dangerous precedent, pre-empting a much-needed public debate.}

$\longrightarrow$ he human cloning debate has revealed the growing political importance of bioethics committees in the regulation of new technologies. Confronted with public concern about human cloning, the instant reflex of political leaders worldwide has been to call on the nearest bioethics committee for advice.

The political weight now being given to such committees (see pages 323,324 ) requires a re-examination of both their operation and their place in the democratic process of decision-making. Such committees are ultimately a small group of unelected individuals. The danger to democracy is that although such committees have no legislative powers, they often exert considerable influence on legislators unfamiliar with complex scientific and ethical issues.

The French committee's ruling should serve as a reminder of this danger. To its credit, the committee has produced an excellent 49page overall review of cloning, with the scientific issues set out in a form which even the least scientifically literate members of the French National Assembly could grasp. Where the committee errs is in the nine pages devoted to ethical aspects of human cloning. Members of the committee concede that all the various ethical arguments it puts forward could be individually contested, but maintain that, taken together, they support a ban on cloning. That conclusion remains contentious. But the essential point is that, in deciding to take a moral position on human cloning, the committee has gone beyond its role, which should simply be to clarify the debate and promote informed public debate.

The big risk is that politicians will use such ready-made solutions as an excuse to abdicate their duty to shape their legislative and constitutional provisions on bioethics to the religious, moral and cultural traditions of society, as well as to the dominant streams of contemporary thought. For example, Jacques Chirac, the French president, wasted no time in using the committee's report to support the popu- lar political stance of calling for an international ban on the use of human cloning for reproduction.

Questions about the democratic legitimacy of bioethics committees also seem to have escaped Chirac, who proudly declared that the ethics committee had admirably fulfilled its role of telling the government "what should be done" in the face of a bioethical problem. But giving ethics committees this role short-circuits the democratic process by pre-empting wide public debate.

On issues such as human cloning, where emotions run high, ethical committees have an even greater responsibility to provide a measured response. Indeed, in cloning and other such situations, ethics committees are often the last rampart against a stampede of irrational and opportunistic political judgement. A report by the World Health Organization's working group on cloning argues that opposition to human cloning "has prompted legislators and other policy-makers to act out of 'moral panic' rather than from considered deliberation".

The International Bioethics Committee of Unesco is scheduled this week to release an opinion on human cloning. Its job has been made awkward by the premature declaration of Federico Mayor, Unesco's director general, that "human beings should not be cloned under any circumstances", and his limited remit that the committee should verify whether the draft Unesco "universal declaration on the human genome and human rights" outlaws cloning.

In fact, the committee is deeply divided. It should also ask Mayor for more time and for an enlarged remit that would allow it to produce a more comprehensive account of the complex issues involved. It would be doing a service to public debate if it were then to explain the basis of the divergent opinions. Meanwhile, bioethics committees elsewhere should ensure that they avoid becoming undemocratic bastions of premature and forced consensus.

\section{A need for endorsement?}

\section{Science studiers and their scientist critics should concentrate on constructive engagement.}

$\Lambda$ dispute at the Institute of Advanced Study at Princeton about a decision not to appoint a historian of science to a position in social sciences (see page 325) may reflect the grey area that can exist between objective assessment of research quality and vehement opposition to ideas. A central issue is said to have been the way in which sociologists and others analyse the social dimensions of science through the discipline known as 'science studies'. More specifically, hostility that has developed among some scientists against the part of these studies known as the 'sociology of scientific knowledge' is being blamed for the failure of the proposed appointment of an individual sympathetic to this approach to generate the required support.

That hostility is understandable. The status of scientific knowledge is approached by the two sides very differently. Scientists tend to see this knowledge as a form of truth embedded in nature, waiting to be revealed by their experimental and theoretical skills. Some sociologists of science, in contrast, prefer to present this 'truth' as the product of negotiations between scientists - hence the criticism from natural scientists that they present a 'relativist' or 'idealist' view of scientific knowledge.

The Princeton decision, and debates elsewhere in the US academic community, reflects the fact that careers are now at stake amid heated - sometimes vitriolic - exchanges generated in what has come to be known as the Science Wars (see Briefing, pages 331-335). Scientists, rightly suspicious of relativism, should nevertheless be circumspect in pursuing this debate. If, as a result of forthcoming meetings between scientists and sociologists of science, the former come to appreciate the virtues of many aspects of science studies, they should say so, loudly and clearly. Good scholarship is at risk in the current climate. 